Correspondence

José A. Bengoechea

jabengoechea@hsd.es

Received 22 June 2005

Revised 4 November 2005

Accepted 15 November 2005

\section{The uptake of a Klebsiella pneumoniae capsule polysaccharide mutant triggers an inflammatory response by human airway epithelial cells}

\author{
Verónica Regueiro, ${ }^{1,3}$ Miguel A. Campos, ${ }^{1,3}$ Jaume Pons, ${ }^{2,3}$ \\ Sebastián Albertí ${ }^{3,4}$ and José A. Bengoechea ${ }^{1,3}$ \\ 1,2Unidad de Investigación, Hospital Universitario Son Dureta ${ }^{1}$ and Servicio de Inmunología, \\ Hospital Universitario Son Dureta², Andrea Doria 55, 07014 Palma Mallorca, Spain \\ ${ }^{3}$ Institut Universitari d'Investigacions en Ciències de la Salut (IUNICS), Palma de Mallorca, \\ Spain \\ ${ }^{4}$ Área de Microbiología, Departamento de Biología, Universidad de las Islas Baleares, Palma \\ de Mallorca, Spain
}

\begin{abstract}
The means by which airway epithelial cells sense a bacterial infection and which intracellular signalling pathways are activated upon infection are poorly understood. A549 cells and human primary airway cells (NHBE) were used to investigate the response to infection with Klebsiella pneumoniae. Infection of A549 and NHBE with K. pneumoniae 52K10, a capsule polysaccharide (CPS) mutant, increased the surface levels of ICAM-1 and caused the release of IL-8. By contrast, the wild-type strain did not elicit these responses. Consistent with a functional role for these responses, there was a correlation between ICAM-1 levels and the number of adherent leukocytes on the epithelial cell surface. In addition, treatment of neutrophils with IL-8 enhanced their ability to kill K. pneumoniae. Strain 52K10 was internalized by A549 cells more efficiently than the wild-type, and when infections with $52 \mathrm{~K} 10$ were performed in the presence of cytochalasin $\mathrm{D}$ the inflammatory response was abrogated. These findings suggest that cellular activation is mediated by bacterial internalization and that CPS prevents the activation through the blockage of bacterial adhesion and uptake. Collectively, the results indicate that bacterial internalization by airway epithelial cells could be the triggering signal for the activation of the innate immune system of the airway. Infection of A549 cells by $52 \mathrm{~K} 10$ was shown to trigger the nuclear translocation of NF- $\kappa \mathrm{B}$. Evidence is presented showing that $52 \mathrm{~K} 10$ activated IL- 8 production through Toll-like receptor (TLR) 2 and TLR4 pathways and that A549 cells could use soluble CD14 as TLR co-receptor.
\end{abstract}

\section{INTRODUCTION}

One of the largest epithelial surfaces of humans is located in the respiratory tract, which needs to be protected without compromising its functionality. In addition to serving as a physical barrier, airway epithelial cells react against insults such as cigarette smoke or air pollutants, mounting an inflammatory response. This response includes the production of pro-inflammatory and chemoattractant cytokines and the cell-surface expression of the adhesion molecule ICAM-1 (CD54) (Bayram et al., 1998; Hellermann et al., 2002; Hoshino et al., 2001; Mio et al., 1997; Pathmanathan

\footnotetext{
Abbreviations: CPS, capsule polysaccharide; EMSA, electrophoretic mobility shift assay; GPI, glycosylphosphatidylinisotol; MFI, mean fluorescence intensity; PDTC, pyrrolidine dithiocarbamate; rMFI, relative mean fluorescence intensity; NHBE, normal human bronchial epithelium; TLR, Toll-like receptor.
}

et al., 2003; Witherden et al., 2004). Airway epithelial cells also interact with microbial pathogens, which should be rapidly killed or otherwise they may easily reach the bloodstream. There are reports showing that infection of airway epithelial cells by pathogens such as Streptococcus pneumoniae, Mycoplasma pneumoniae and group B streptococci triggers the secretion of IL-8 and increases the surface levels of ICAM-1 (Doran et al., 2002; Mikamo et al., 2004; Murdoch et al., 2002; Yang et al., 2002). These responses have been related to the recruitment of neutrophils into airways (Look et al., 1992; Tosi et al., 1992, 1992), which is a common histological finding in patients with pneumonia independently of the infecting micro-organism. The current evidence shows that IL-8 targets neutrophils to sites of attack through its chemoattractant and activating properties (Nakamura et al., 1991), and the interaction of ICAM-1 with $\mathrm{CD} 18 / \beta 2$ integrin-containing receptor on leukocytes is crucial for leukocyte migration (Look et al., 1992; Nakajima 
et al., 1994, 1995). In addition there is evidence that ICAM-1 enhances the antimicrobial activity of alveolar macrophages and neutrophils (Bullard et al., 1995; O'Brien et al., 1999; Paine et al., 2002) and it also mediates cellular cross-talk between parenchymal and alveolar macrophages (Lee et al., 2004). However, it is still poorly understood how airway epithelial cells sense a bacterial infection and which intracellular signalling pathways are activated upon infection.

Klebsiella pneumoniae is an important cause of communityacquired pneumonia in individuals with impaired pulmonary defences and is a major pathogen for nosocomial pneumonia. Pulmonary infections are often characterized by a rapid clinical course, thereby leaving little time for an effective antibiotic treatment, which is increasingly difficult due to the emergence of multidrug-resistant strains. In turn, this emphasizes the importance of pulmonary innate defence systems to clear K. pneumoniae infections. In this scenario, airway epithelial cells might play an important role by, on the one hand, early detection of the infection and, on the other hand, elimination of bacteria.

We recently started to investigate the interplay between $K$. pneumoniae and airway epithelial cells. Our results showed that poorly capsulated K. pneumoniae strains and capsuledeficient mutants were internalized by A549 cells whereas heavily capsulated strains were not (Cortes et al., 2002a, b). These findings are in good agreement with those obtained by other authors (Favre-Bonte et al., 1999; Oelschlaeger \& Tall, 1997). The evidence indicates that capsule polysaccharide (CPS) allows $K$. pneumoniae to avoid uptake by human epithelial cells (Cortes et al., 2002a, b; Favre-Bonte et al., 1999; Oelschlaeger \& Tall, 1997). However, to the best of our knowledge the cellular responses upon infection have not been studied.

In the present study, we analysed the epithelial cell response to $K$. pneumoniae using A549 cells and human primary airway cells (NHBE).

\section{METHODS}

Bacterial strains, growth conditions and reagents. $K$. pneumoniae 52145 is a clinical isolate (serotype O1:K2) previously described (Nassif et al., 1989). The isogenic mutant 52K10, not expressing CPS, has been recently described (Cortes et al., 2002b). Bacteria were grown in Luria-Bertani (LB) medium at $37^{\circ} \mathrm{C}$. When appropriate, antibiotics were added to the medium at the following concentrations: ampicillin, $100 \mu \mathrm{g} \mathrm{ml}^{-1}$; chloramphenicol, $25 \mu \mathrm{g}$ $\mathrm{ml}^{-1}$; and kanamycin, $20 \mu \mathrm{g} \mathrm{ml}^{-1}$.

Recombinant human CD14 was purchased from RD systems. Blocking antibodies against Toll-like receptors TLR2 (clone TLR2.1; Lien et al., 1999) and TLR4 (clone HTA125; Shimazu et al., 1999) were purchased from Hycult biotechnology.

Cell culture and infections. Monolayers of human lung carcinoma cells (A549, ATCC CCL185) derived from type II pneumocytes were grown to confluence in RPMI 1640 medium supplemented with $10 \%$ heat-inactivated fetal bovine serum plus penicillin and streptomycin in 24- or 96 -well tissue culture plates at $37^{\circ} \mathrm{C}$ in a water-saturated atmosphere of $95 \%$ air and $5 \% \mathrm{CO}_{2}$. Primary human airway epithelial cells (NHBE; Cambrex) were maintained in bronchial epithelial basal medium (Cambrex) following the manufacturer's instructions. Before infection, A549 or NHBE cells were washed three times with PBS and infections were performed at a m.o.i. of 100:1 unless otherwise indicated. Cell viability was assessed by trypan blue dye exclusion and it was $>95 \%$ even after $12 \mathrm{~h}$ of infection.

Flow cytometry. Monolayers of epithelial cells were detached by incubation with trypsin/EDTA and washed with $0 \cdot 1 \%$ sodium azide in PBS. To analyse the expression of ICAM-1, cells were incubated with optimal concentrations of monoclonal anti-human CD54 (ICAM-1) clone 8.4A6 (IgG1 isotype) or IgG1 isotype-matched FITC-labelled antibodies (Sigma). To analyse the expression of CD14, TLR2 and TLR4, cells were incubated with anti-CD14 PE conjugated (clone My4, $10 \mu \mathrm{g} \mathrm{ml}^{-1}$; Beckman Coulter), anti-TLR2 (clone TL2.1, $10 \mu \mathrm{g} \mathrm{ml}^{-1}$; ebioscience), anti-TLR4 (clone HTA125, $10 \mu \mathrm{g} \mathrm{ml}^{-1}$; ebioscience) PE conjugated or IgG2a, $\kappa$ isotype labelled antibodies. Cells were incubated with the antibodies at room temperature $\left(22-25^{\circ} \mathrm{C}\right)$ for $15 \mathrm{~min}$. Analysis was performed using a Cultek Epics XL flow cytometer. At least 8000 cells were acquired in every experiment. The levels of ICAM-1, CD14, TLR2 and TLR4 were expressed as relative mean fluorescence intensity (rMFI) measured in arbitrary units and the nonspecific binding was corrected by subtraction of MFI values corresponding to isotype-matched antibodies.

Cytokine stimulation assay. Monolayers of epithelial cells were infected and after $2 \mathrm{~h}$ of infection supernatants were carefully removed from the wells and the monolayers were washed twice with PBS. Fresh medium plus gentamicin $\left(100 \mu \mathrm{g} \mathrm{ml}^{-1}\right)$ was then added and the plates were incubated for $18 \mathrm{~h}$. Supernatants were collected, cell debris was removed by centrifugation, and samples were frozen at $-80^{\circ} \mathrm{C}$.

In time-course experiments monolayers were infected and the supernatants were collected at the indicated time points; cell debris was removed by centrifugation and the cleared supernatants stored at $-80{ }^{\circ} \mathrm{C}$.

Cytokines in the supernatants were determined using a commercial kit that allows the simultaneous detection of six cytokines in the sample by flow cytometry (Cytometric Bead Array Kit; BD Biosciences). The cytokines measured were IL- $1 \beta$, IL-6, TNF $\alpha$, IL-8, IL-10 and IL-12p70. The assay sensitivity for each cytokine was $7 \cdot 2 \mathrm{pg} \mathrm{ml}^{-1}$ for IL- $1 \beta$, $2 \cdot 5 \mathrm{pg} \mathrm{ml}^{-1}$ for IL-6, $3 \cdot 7 \mathrm{pg} \mathrm{ml}^{-1}$ for TNF $\alpha, 3 \cdot 6 \mathrm{pg} \mathrm{ml}^{-1}$ for IL-8, $3 \cdot 3 \mathrm{pg} \mathrm{ml}^{-1}$ for IL-10 and $1.9 \mathrm{pg} \mathrm{ml}^{-1}$ for IL-12p70. Experiments were run in duplicate and repeated at least three times.

Invasion assay. After $2 \mathrm{~h}$ of infection, monolayers were washed twice with PBS and then incubated for a further $2 \mathrm{~h}$ with fresh medium plus gentamicin $\left(100 \mu \mathrm{g} \mathrm{ml}^{-1}\right)$ to kill extracellular bacteria. This treatment was long enough to kill all extracellular bacteria. Epithelial monolayers were washed three times with PBS, and cells were lysed with $0.5 \%$ Triton X-100 and titrated for viable counts of intracellular bacteria. Experiments were carried out in triplicate on at least two independent occasions and results expressed as c.f.u. per monolayer.

Preparation of nuclear and cytosolic extracts. Nuclear and cytosolic proteins were extracted from approximately $5 \times 10^{6}$ cells as previously described (Elewaut et al., 1999) with minor modifications. Briefly, A549 cells were washed with ice-cold PBS and suspended in hypotonic buffer (10 mM HEPES, $10 \mathrm{mM} \mathrm{KCl}, 2 \mathrm{mM}$ $\mathrm{MgCl}_{2}, 1 \mathrm{mM}$ DTT, $0 \cdot 1 \mathrm{mM}$ EDTA, $0 \cdot 2 \mathrm{mM} \mathrm{NaF}, 0 \cdot 2 \mathrm{mM} \mathrm{Na}_{3} \mathrm{VO}_{4}$, $1 \mu \mathrm{g}$ leupeptin $\mathrm{ml}^{-1}, 0 \cdot 4 \mathrm{mM}$ PMSF). The cells were left on ice for $15 \mathrm{~min}$ and a cytosolic preparation was made by addition of Nonidet P-40 (final concentration of $0 \cdot 1 \%$ ) followed by centrifugation 
(6500 r.p.m., $3 \mathrm{~min}, 4^{\circ} \mathrm{C}$ ). The supernatant was collected as the cytosolic fraction. The remaining pellet was resuspended in extraction buffer $(50 \mathrm{mM}$ HEPES, $50 \mathrm{mM} \mathrm{KCl}, 300 \mathrm{mM} \mathrm{NaCl}, 0 \cdot 1 \mathrm{mM}$ EDTA, $1 \mathrm{mM}$ DTT, $10 \%$, v/v, glycerol, $0.2 \mathrm{mM} \mathrm{NaF}, 0.2 \mathrm{mM}$ $\mathrm{Na}_{3} \mathrm{VO}_{4}, 0 \cdot 1 \mathrm{mM}$ PMSF) and incubated on ice for $20 \mathrm{~min}$ with agitation. The nuclear proteins in the supernatant were recovered after centrifugation $\left(12000 \mathrm{~g}, 20 \mathrm{~min}, 4^{\circ} \mathrm{C}\right)$ to remove nuclear debris. Proteins present in extracts were quantified using the Coomassie protein assay (Pierce) referenced against a bovine serum albumin standard and stored in aliquots at $-80^{\circ} \mathrm{C}$.

Electrophoretic mobility shift assay (EMSA). The NF- $\kappa$ B oligonucleotide probe (5'-GCCTGGGAAAGTCCCCTCAACT-3') was labelled with biotin using a commercial kit as recommended by the manufacturer (Biotin 3' end DNA labelling kit, Pierce). Nuclear proteins $(20 \mu \mathrm{g})$ were incubated for $20 \mathrm{~min}$ at $22^{\circ} \mathrm{C}$ with $50 \mathrm{fmol}$ of the oligonucleotide probe in binding buffer $[100 \mathrm{mM}$ Tris, $500 \mathrm{mM}$ $\mathrm{KCl}, 10 \mathrm{mM}$ DTT, pH 7·5, 2.5\%, v/v, glycerol, $5 \mathrm{mM} \mathrm{MgCl}_{2}, 1 \mu \mathrm{g}$ poly $(\mathrm{dI} \cdot \mathrm{dC})]$. After incubation, the reaction products were analysed by $6 \%$ PAGE using Tris/borate/EDTA running buffer $(90 \mathrm{mM}$ Tris, $90 \mathrm{mM}$ boric acid, $2 \mathrm{mM}$ EDTA, $\mathrm{pH} 8 \cdot 3$ ). Bound and free DNAs were detected using a commercial kit as recommended by the manufacturer (LightShift Chemiluminiscent EMSA kit, Pierce).

Immunoblotting for $\mathbf{I} \boldsymbol{k} \mathbf{B} \boldsymbol{\alpha}$. Cytoplasmic proteins (15 $\mu \mathrm{g})$ were separated by $10 \%$ SDS-PAGE, electrotransferred to nitrocellulose membrane and blocked with $3 \%$ skimmed milk in PBS. Immunostaining for $\mathrm{I} \kappa \mathrm{B} \alpha$ was performed with polyclonal rabbit anti-I $\kappa \mathrm{B} \alpha$ antibody (Santa Cruz Biotechnology). Immunoreactive bands were visualized by incubation with swine anti-rabbit immunoglobulins conjugated to horseradish peroxidase (Dako P0217) using the SuperSignal West-dura system (Pierce). The same blots were reprobed with polyclonal anti-human tubulin antibody to control that equal amounts of proteins were loaded in each lane.

Adhesion of neutrophils to epithelial cells. Neutrophils were isolated from healthy donors by a standard Ficoll gradient centrifugation technique and adjusted to a final concentration of about $10^{6}$ cells $\mathrm{ml}^{-1}$. A549 epithelial cell monolayers grown to confluence in 24-well plates were washed twice with PBS and neutrophils were added $\left(0 \cdot 5 \times 10^{6}\right.$ per well $)$ in a final volume of $250 \mu$ RPMI 1640 . When indicated, monolayers were infected for $9 \mathrm{~h}$ with $\mathrm{K}$. pneumoniae 52K10. In these experiments, monolayers were washed of bacteria, and gentamicin was added for $2 \mathrm{~h}$ to kill remaining extracellular bacteria before adding neutrophils. When indicated (see Fig. 3), anti-ICAM-1 blocking antibodies (clone HA58, $50 \mu \mathrm{g} \mathrm{ml}^{-1}$; Yamamura et al., 1996) or isotype-matched antibodies (IgG1, $\kappa$ ) were added to monolayers $1 \mathrm{~h}$ before adding neutrophils and they were not removed during the adhesion period.

Plates were incubated for $30 \mathrm{~min}$ at $37^{\circ} \mathrm{C}$ and nonadherent neutrophils were then removed by shaking the plates, decanting the supernatant, washing with PBS and decanting. Remaining adherent cells were quantified by measuring the peroxidase content of the wells and comparing these values with peroxidase levels in serially diluted samples of neutrophils as outlined below. After washing away nonadherent cells, $250 \mu \mathrm{l} 0 \cdot 5 \%$ hexadecyltrimethyl ammonium bromide was added to each well to extract cellular peroxidase. A $50 \mu \mathrm{l}$ aliquot from each well was added to a 96-well assay plate, plus $150 \mu \mathrm{l}$ substrate (o-dianisidine, $1 \mathrm{mg} \mathrm{ml}^{-1}$ in $0 \cdot 1 \mathrm{M}$ phosphate buffer containing $0.001 \% \mathrm{H}_{2} \mathrm{O}_{2}, \mathrm{pH} 6.5$ ). After 15 min incubation, absorbance was measured at $450 \mathrm{~nm}$. The number of adherent cells was determined by comparing peroxidase activity with that of serial dilutions of a standard number of purified neutrophils. In preliminary experiments it was found that A549 cells did not contain significant endogenous peroxidase, and that negligible peroxidase released from neutrophils occurred during the adhesion assay. In agreement with recent reports (Videm \& Strand, 2004), treatment of neutrophils with IL-8
(80 $\mathrm{ng} \mathrm{ml}^{-1}$ for $1 \mathrm{~h}$ ) neither affected peroxidase content nor caused its release. Experiments were run in duplicate on three independent occasions using neutrophils isolated from a different donor each time.

Neutrophil-killing ability. Neutrophils were isolated by a standard Ficoll gradient centrifugation technique and adjusted to a final concentration of about $10^{6} \mathrm{cells} \mathrm{ml}^{-1}$ in RPMI 1640. For the assay, $10^{5}$ neutrophils were incubated with $10^{6}$ bacteria that were either opsonized ( $15 \mathrm{~min}$ on ice with $25 \%$ normal human serum in a final volume of $200 \mu \mathrm{l}$ ) or nonopsonized. After $1 \mathrm{~h}$ incubation at $37^{\circ} \mathrm{C}$, the contents of each tube were plated on LB agar to determine the numbers of viable bacteria. Killing ability was indicated by the decrease in total number of bacteria (i.e. bacteria associated with neutrophils and nonadherent bacteria in the supernatant). The killing index $\left(K_{\mathrm{i}}\right)$ was determined as the ratio of the initial number of bacteria at time zero to the number after $1 \mathrm{~h}$ incubation with neutrophils. The experiments were carried out in duplicate and repeated at least three times with neutrophils isolated from different donors.

Statistical methods. Statistical analyses were performed using analysis of variance (ANOVA) or the two-sample $t$ test or, when the requirements were not met, by the Mann-Whitney $U$ test. $P<0 \cdot 05$ was considered statistically significant. Results are given as means \pm SE $(n \geqslant 3)$.

\section{RESULTS}

\section{A K. pneumoniae CPS mutant induces ICAM-1 expression and IL-8 secretion by human airway epithelial cells}

ICAM-1 levels on the surface of cultured human airway epithelial cell monolayers were examined by flow cytometry. The results showed that A549 and NHBE cells expressed constitutive levels of ICAM-1 (Fig. 1a, b, white bars). Infection with the wild-type K. pneumoniae strain, 52145, did not increase ICAM-1 levels on the surface of either A549 cells or NHBE cells (Fig. 1a, b, grey bars). We sought to determine whether the presence of CPS on the bacterial surface may prevent the activation of cellular signalling pathways responsible for the upregulation of ICAM-1 expression. Indeed, infection of A549 and NHBE cells with strain 52K10, an isogenic CPS mutant of 52145, increased the surface levels of ICAM-1 (Fig. 1a, b, black bars). Examination of the relationship between time of infection, inoculum and induction of ICAM-1 expression by A549 cells revealed that shorter times of infection and lower inocula induced less ICAM-1 (data not shown). Finally, we tested whether the expression of other surface molecules could be affected by the infection with 52K10. Neither the levels of CD55 nor the levels of MHC class I expressed by A549 cells were altered (data not shown), indicating that infection with $52 \mathrm{~K} 10$ was not causing a general alteration in the expression of surface molecules.

To examine the effect of $K$. pneumoniae infection on other inflammatory mediators, we performed enzyme-linked immunoassays for release by epithelial cells of IL- $1 \beta$, IL-6, $\mathrm{TNF} \alpha$, IL-8, IL-10 and IL-12p70. Infection of A549 and NHBE cells with $K$. pneumoniae 52145 did not elicit the secretion of IL-1 $\beta$, IL-6, TNF $\alpha$, IL-10, IL-112p70 (data not shown) and IL-8 (Fig. 2a) whereas infection with strain 


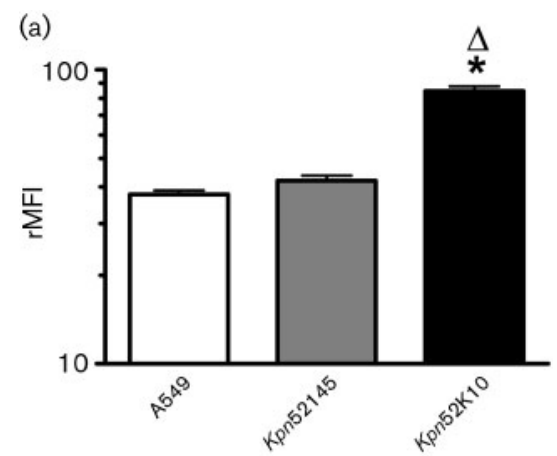

(b)

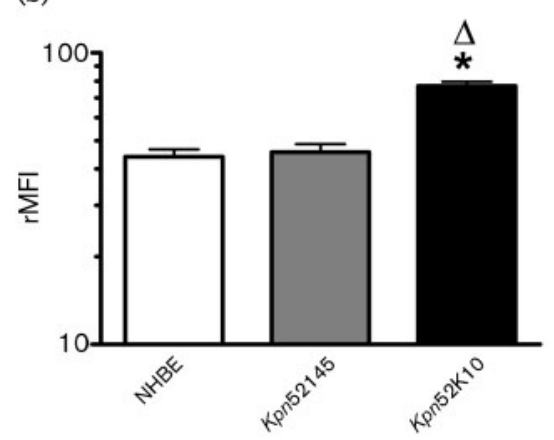

Fig. 1. Flow cytometric analysis of ICAM-1 expression by human airway epithelial cells after infection: (a) A549 cells; (b) NHBE cells. Cells were left uninfected (white bars), or infected with K. pneumoniae 52145 (Kpn52145; grey bars) or 52K10 (Kpn52K10; black bars). After $9 \mathrm{~h}$ of infection cells were detached, stained and analysed by flow cytometry. Results are expressed as rMFI (MFI values obtained after staining with antiICAM antibodies minus MFI values obtained after staining with isotype-matched antibodies) measured in arbitrary units. MFI values of A549 cells and NHBE cells incubated with isotypematched antibodies were $10 \pm 3$ and $22 \pm 5$, respectively. ${ }^{*} P<0.05$, a significant difference from infected cells with 52145; ${ }^{\Delta} P<0 \cdot 05$, a significant difference from uninfected cells.

52K10 triggered the secretion of IL-8 (Fig. 2a) but none of the other cytokines (data not shown). Time-course experiments showed that there was a correlation between secretion of IL-8 by A549 cells (Fig. 2b) and by NHBE cells (Fig. 2c) and the duration of infection with strain $52 \mathrm{~K} 10$. In contrast, strain 52145 did not elicit the secretion of IL-8 even after $12 \mathrm{~h}$ of infection (Fig. 2b, c). Neither 52145 nor $52 \mathrm{~K} 10$ induced the secretion of IL- $1 \beta$, IL- 6 , TNF $\alpha$, IL-10 or IL12 p70 by A549 and NHBE cells after $12 \mathrm{~h}$ of infection.

An important component of the response of the airways to bacterial infections is the infiltration of neutrophils into lung tissues. The current evidence shows that ICAM-1 is crucial for leukocyte migration (Look et al., 1992; Nakajima et al., 1994, 1995). To study the functional activity of ICAM1 expressed by A549 cells, we quantified neutrophil adherence to A549 monolayers. In the absence of stimulus, we did detect neutrophil adherence to cells (Fig. 3). Infection of A549 cells with $K$. pneumoniae 52K10 (9 h) increased the

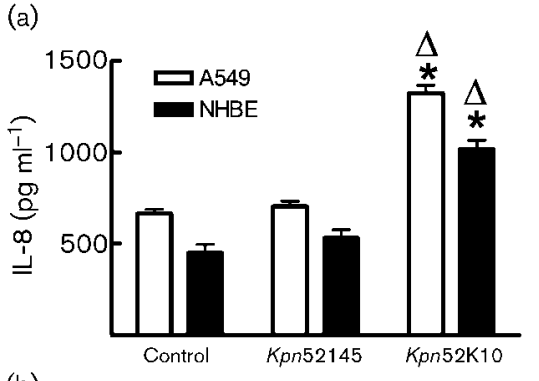

(b)

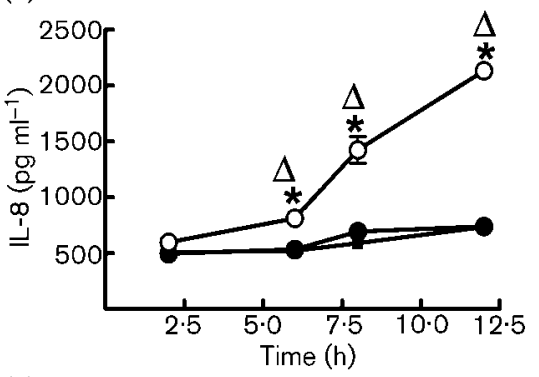

(c)

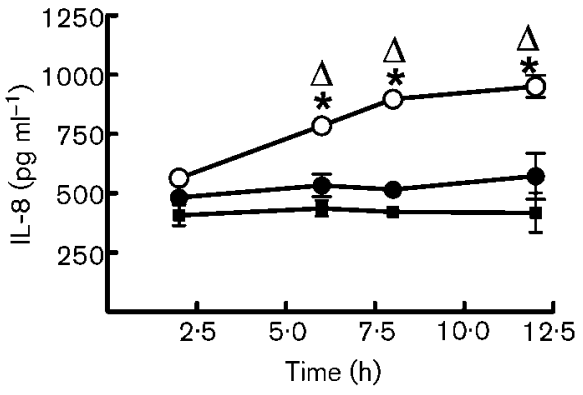

Fig. 2. Levels of IL-8 secreted into culture medium by human airway epithelial cells. (a) Cells were left uninfected (control), or infected with $K$. pneumoniae 52145 (Kpn52145) or 52K10 (Kpn52K10) for $2 \mathrm{~h}$. Supernatants were analysed for IL-8; the values presented are means $\pm \mathrm{SD}$. (b, c) A549 cells (b) or NHBE cells (c) were left uninfected $(\boldsymbol{\square})$, or infected with $K$. pneumoniae $52145(0)$ or $52 \mathrm{~K} 10(\bigcirc)$ for 2-12 h. Supernatants were analysed for IL-8; the values presented are means $\pm \mathrm{SD}$. ${ }^{\star} P<0.05$, a significant difference from infected cells with 52145. ${ }^{\Delta} P<0 \cdot 05$, a significant difference from uninfected cells.

expression of ICAM-1 (rMFI values $80 \pm 7$ ) and this correlated with an increased number of adherent neutrophils (Fig. 3). This increased epithelial-neutrophil adherence after infection was inhibited by treating the monolayers with anti-ICAM-1 blocking antibodies (Fig. 3).

Taking into account that A549 cells secreted IL-8 upon infection we asked whether this chemokine may affect neutrophil adherence. However, treatment of neutrophils with IL-8 (15 min before addition of leukocytes to the monolayers) did not further increase the number of adherent neutrophils on infected cells (data not shown).

Finally we studied the ability of neutrophils to kill $K$. pneumoniae. Killing indices $\left(K_{\mathrm{i}}\right)$ higher than 1.0 indicate efficient killing and indices less than $1 \cdot 0$ indicate cell-associated 


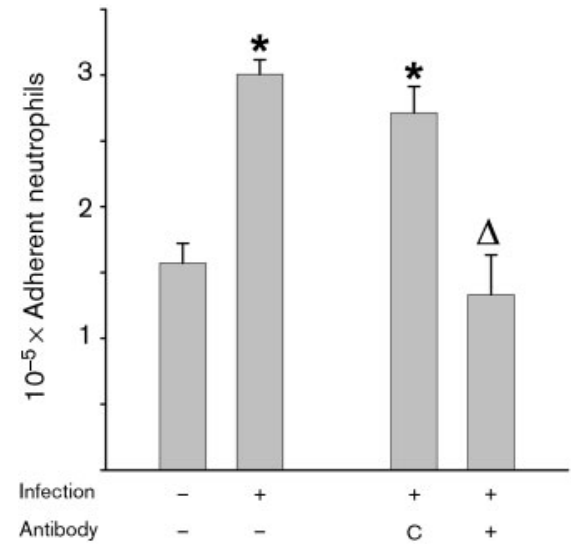

Fig. 3. Neutrophil adherence to A549 cells is enhanced by infection. Neutrophils were isolated and allowed to adhere to A549 monolayers that had been left uninfected or had been infected for $9 \mathrm{~h}$ with $K$. pneumoniae 52K10. The monolayers were washed of bacteria, and gentamicin was added for $2 \mathrm{~h}$ to kill remaining extracellular bacteria before adding neutrophils. When indicated, anti-ICAM-1 blocking antibodies (+) or, as control (C), isotype-matched antibodies $(\operatorname{lgG} 1, \kappa)$ were added to monolayers $1 \mathrm{~h}$ before adding neutrophils and they were not removed during the adhesion period. Adherent cells were quantified by measuring the peroxidase activity of the wells and comparing these values with peroxidase levels in serially diluted samples of neutrophils. ${ }^{*} P<0.05$, a significant difference from uninfected cells; ${ }^{\Delta} P<0.05$, a significant difference from infected cells untreated with antibodies.

(possibly intracellular) bacterial multiplication. Strains 52145 and $52 \mathrm{~K} 10$ were not killed by neutrophils $\left(K_{\mathrm{i}} 1 \cdot 01 \pm\right.$ 0.2 and $0.93 \pm 0.4$ respectively), whether or not the bacteria had been previously incubated with human sera $\left(K_{\mathrm{i}} 1 \cdot 20 \pm\right.$ $0 \cdot 3$ and $0.91 \pm 0 \cdot 2$ respectively). However, treatment of neutrophils with IL-8 ( $80 \mathrm{ng} \mathrm{ml}^{-1} 15 \mathrm{~min}$ before infection) significantly increased their killing ability. Thus, the $K_{\mathrm{i}}$ for 52145 was $71 \pm 4 \cdot 6$ (a 70 -fold increase) and the $K_{\mathrm{i}}$ for $52 \mathrm{~K} 10$ was $108 \pm 9 \cdot 8$ (a 100 -fold increase). In this case, pretreatment of bacteria with human sera further enhanced the killing ability of neutrophils: the $K_{\mathrm{i}}$ for 52145 was $492 \pm 20$ and the $K_{\mathrm{i}}$ for $52 \mathrm{~K} 10$ was $627 \pm 17$. Of note, 52145 was more resistant than $52 \mathrm{~K} 10$ to killing by neutrophils $(P<0 \cdot 05)$. On the other hand, it is known that IL- 8 triggers the release of antimicrobial factors by neutrophils (Chertov et al., 1996) and therefore the results obtained in the presence of IL- 8 could be due to the action of these factors. To clarify this issue, we incubated both K. pneumoniae strains in the cell culture media from neutrophils that had been cultivated in the presence of IL-8. Under these conditions we did not find any change in the $K_{\mathrm{i}}$ (data not shown).

\section{Intracellular bacteria trigger the inflammatory response by human airway epithelial cells}

Various studies have shown that poorly capsulated $K$. pneumoniae strains and CPS mutants adhere to and invade epithelial cells more efficiently than heavily capsulated strains (Cortes et al., 2002a, b; Favre-Bonte et al., 1999; Oelschlaeger \& Tall, 1997). Therefore, activation of the inflammatory programme could be associated with bacterial uptake, bacterial adhesion or both.

Gentamicin protection assays showed that $52 \mathrm{~K} 10$ was internalized by A549 cells more efficiently than $52145(2 \cdot 1 \pm$ $3 \cdot 4 \times 10^{3}$ c.f.u. per monolayer and $1 \cdot 4 \pm 0 \cdot 5 \times 10^{1}$ c.f.u. per monolayer respectively; $P<0 \cdot 05)$. In addition, 52K10 attached to A549 cells more efficiently than the wild-type strain $\left(3 \cdot 2 \pm 1 \cdot 4 \times 10^{5}\right.$ c.f.u. per monolayer and $2 \cdot 5 \pm 1 \cdot 0 \times$ $10^{1}$ c.f.u. per monolayer respectively; $\left.P<0 \cdot 05\right)$. To examine whether intracellular bacteria were responsible for the induction of ICAM-1 expression, gentamicin was added $2 \mathrm{~h}$ post-infection to kill extracellular bacteria and the surface levels of ICAM-1 were measured $4 \mathrm{~h}$ later. Infection of A549 cells with 52K10 increased the levels of ICAM-1 (Fig. 4a). To determine whether adherent bacteria would also increase the expression of ICAM-1, the infections were performed in the presence of cytochalasin D, an inhibitor of bacterial uptake by eukaryotic cells. Cytochalasin D abrogated the internalization of $52 \mathrm{~K} 10\left(4 \cdot 0 \pm 0 \cdot 7 \times 10^{1}\right.$ c.f.u. per monolayer versus $2 \cdot 1 \pm 3 \cdot 4 \times 10^{3}$ c.f.u. per monolayer in the absence of the drug; $P<0 \cdot 05)$ whereas the adhesion of the mutant was not affected $\left(2 \cdot 8 \pm 1 \cdot 2 \times 10^{5}\right.$ c.f.u. per monolayer versus $3 \cdot 2 \pm 1 \cdot 4 \times 10^{5}$ c.f.u. per monolayer in the absence of the drug; $P>0 \cdot 05)$. In these conditions, infection with 52K10 did not increase the levels of ICAM-1 (Fig. 4b). Gentamicin-treated cells expressed similar levels of ICAM-1 (rMFI $35 \pm 5$ ) as cytochalasin D-treated cells (rMFI 41 \pm 3 ) or uninfected cells (rMFI $39 \pm 4$ ). We asked whether IL-8 secretion was dependent on intracellular bacteria. The results in Fig. 4(c) show that when infections were performed in the presence of cytochalasin D, the secretion of IL-8 was not significantly different from that of uninfected cells and uninfected cells treated with cytochalasin D.

To rule out a nonspecific effect of cytochalasin $\mathrm{D}$ on the activation of A549 cells, we examined the effect of treating A549 cells with cytochalasin D only on TNF $\alpha$-dependent IL-8 production and ICAM-1 upregulation. TNF $\alpha$-treated A549 cells secreted similar amounts of IL- 8 in the presence or in the absence of the drug $\left(1820 \pm 90 \mathrm{pg} \mathrm{ml}^{-1}\right.$ and $1750 \pm$ $60 \mathrm{pg} \mathrm{ml}^{-1}$, respectively). TNF $\alpha$-dependent ICAM-1 upregulation was also not affected by incubation of A549 cells with cytochalasin D (rMFI $60 \pm 6$ in the absence of cytochalasin D versus $67 \pm 9$ in the presence of the drug).

\section{Intracellular bacteria activate NF- $\kappa$ B in human airway epithelial cells}

There are several studies showing that NF- $\kappa \mathrm{B}$ activation is associated with IL-8 secretion and/or an increase of ICAM-1 expression (Mastronarde et al., 1998; Moodie et al., 2004; Nishikawa et al., 1999; Papi et al., 2000; Poynter et al., 2002, 2003).We asked whether infection of A549 cells with $52 \mathrm{~K} 10$ would activate NF- $\kappa \mathrm{B}$ by studying nuclear translocation of this transcriptional factor. EMSAs showed NF- $\kappa \mathrm{B}$ DNA 
(a)

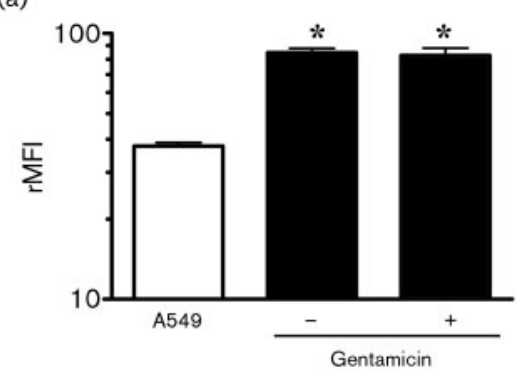

(b)

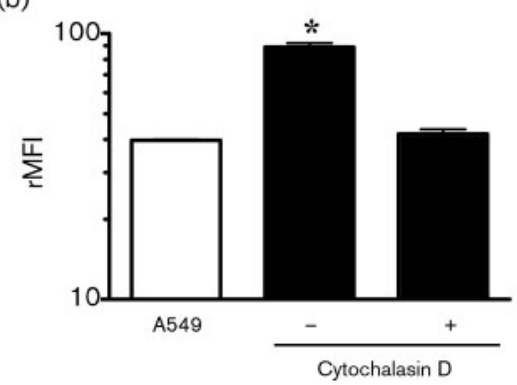

(c)

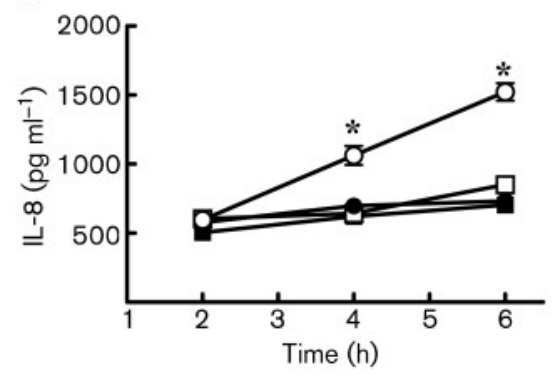

Fig. 4. Intracellular bacteria activate $I C A M-1$ expression and IL-8 secretion in A549 cells. (a) Cells were left uninfected (white bar) or infected with K. pneumoniae 52K10 (black bars). Where indicated, gentamicin was added after $2 \mathrm{~h}$ of infection to kill extracellular bacteria, and $4 \mathrm{~h}$ later cells were detached, stained and analysed by flow cytometry. (b) Cells were left uninfected (white bar) or infected with K. pneumoniae 52K10 (black bars). Where indicated cytochalasin $\mathrm{D}\left(5 \mu \mathrm{g} \mathrm{m}^{-1}\right)$ was added 30 min before infection, to block the uptake of $K$. pneumoniae, and it was maintained during the infection. After $6 \mathrm{~h}$ of infection, cells were detached, stained and analysed by flow cytometry. Results are expressed as rMFI (MFI values obtained after staining with anti-ICAM antibodies minus MFI values obtained after staining with isotype-matched antibodies), in arbitrary units. MFI values of A549 cells incubated with isotype-matched antibodies were $11 \pm 2 .{ }^{*} P<0.05$, a significant difference from uninfected cells. Gentamicin or cytochalasin D did not affect ICAM-1 expression on uninfected cells. The results are representative of three independent experiments run in duplicate. (c) A549 cells were left uninfected ( $\boldsymbol{\square})$, treated with cytochalasin D ( $\square$ ), infected with $K$. pneumoniae $52 \mathrm{~K} 10(\bigcirc)$ or infected with $K$. pneumoniae $52 \mathrm{~K} 10$ in the presence of cytochalasin $\mathrm{D}$ (๑) for 2-12 h. Supernatants were analysed for IL-8; the values presented are means $\pm \mathrm{SD}$. ${ }^{\star} P<0.05$, a significant difference from infected cells in the presence of cytochalasin $D$. binding after 60 min of infection (Fig. 5a, upper panel). Protein binding to the NF- $\kappa \mathrm{B}$ oligonucleotide probe was mediated predominantly by heterodimers of p65 and p50 as demonstrated in supershift assays (data not shown).

One of the major pathways for NF- $\kappa \mathrm{B}$ activation involves the phosphorylation of $\mathrm{I} \kappa \mathrm{B} \alpha$ followed by degradation of the protein, thereby allowing the migration of NF- $\kappa \mathrm{B}$ dimers from the cytoplasm to the nucleus. We analysed the expression levels of $\mathrm{I} \kappa \mathrm{B} \alpha$ in cytoplasmic extracts by immunoblot analysis. $\mathrm{I} \kappa \mathrm{B} \alpha$ degradation was apparent after $60 \mathrm{~min}$ of infection with 52K10 (Fig. 5a, middle panel).

To examine whether bacterial internalization caused NF- $\kappa \mathrm{B}$ activation, bacterial uptake was inhibited by cytochalasin $\mathrm{D}$ and then NF- $\kappa \mathrm{B}$ translocation to the nucleus of A549 cells was assessed. EMSA results demonstrated no NF- $\kappa \mathrm{B}$ DNA binding when infections were performed in the presence of cytochalasin D (Fig. 5b, upper panel). Further, $\mathrm{I} \kappa \mathrm{B} \alpha$ degradation was not detected when infections were performed in the presence of the drug (Fig. 5b, middle panel). Cytochalasin D also inhibited the infection-dependent degradation of $\mathrm{I} \kappa \mathrm{B} \alpha$ in NHBE cells (Fig. 5c, upper panel).

Finally, we asked whether blocking NF- $\kappa \mathrm{B}$ activation would inhibit the infection-dependent induction of ICAM-1 expression. To address this, infections of A549 cells were done in the presence of pyrrolidine dithiocarbamate (PDTC), an inhibitor of NF- $\kappa \mathrm{B}$ activity (Schreck et al., 1992). Flow cytometric analysis revealed that $100 \mu \mathrm{M}$ PDTC inhibited the induction of ICAM-1 expression in response to an infection with $52 \mathrm{~K} 10$ (Fig. 5d). PDTC-treated cells expressed similar levels of ICAM-1 (rMFI 35 \pm 5 ) as uninfected cells (rMFI 39 \pm 4 ).

\section{Role of Toll-like receptors and CD14 in activation of human airway epithelial cells upon $K$. pneumoniae infection}

Toll-like receptors (TLRs) recognize a variety of pathogen products and initiate the activation of NF- $\kappa \mathrm{B}$ and subsequently the production of inflammatory mediators (Janeway \& Medzhitov, 2002). Therefore it can be predicted that TLR-dependent signalling would be important in the recognition of pathogens by A549 cells. Flow cytometric analysis showed that A549 cells expressed TLR2 and TLR4 on their surface (rMFI $15 \pm 3$ and $11 \pm 2$ respectively). To assess the contribution of TLRs to the response against $K$. pneumoniae infection, A549 cells were incubated for $30 \mathrm{~min}$ with anti-TLR2 (clone TL2.1; Lien et al., 1999) or anti-TLR4 (clone HTA125; Shimazu et al., 1999) antibodies, or both, then infected with $52 \mathrm{~K} 10$ and the amount of IL- 8 secreted to the culture medium measured. Anti-TLR2 significantly reduced IL- 8 production by A549 cells whereas anti-TLR4 had a minor effect. The combination of both antibodies had the strongest effect (Fig. 6a). The amount of IL-8 secreted by cells incubated with an isotype-matched antibody (IgG2a, $\kappa$ ) before infection $\left(635 \pm 17 \mathrm{pg} \mathrm{ml}^{-1}\right)$ was not significantly different from that of infected cells $\left(641 \pm 35 \mathrm{pg} \mathrm{ml}^{-1}\right)$. We 
(a)

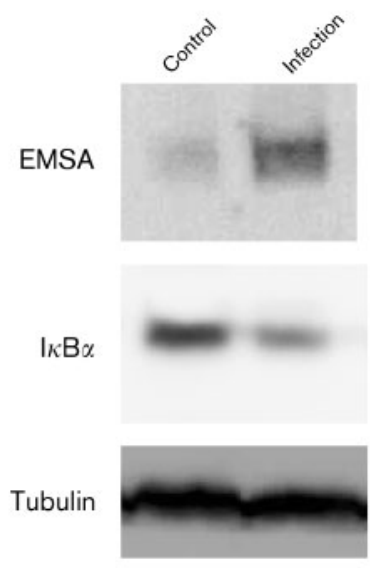

(c)

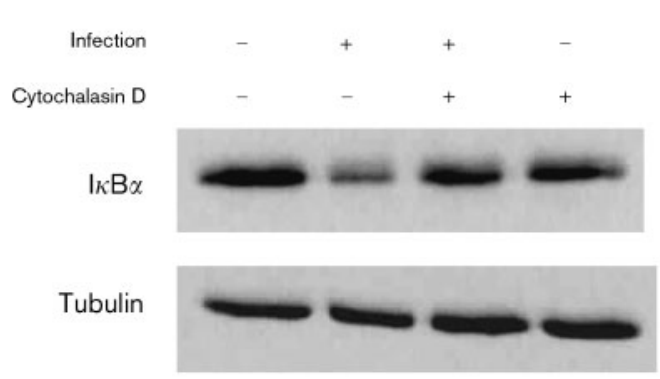

(b)

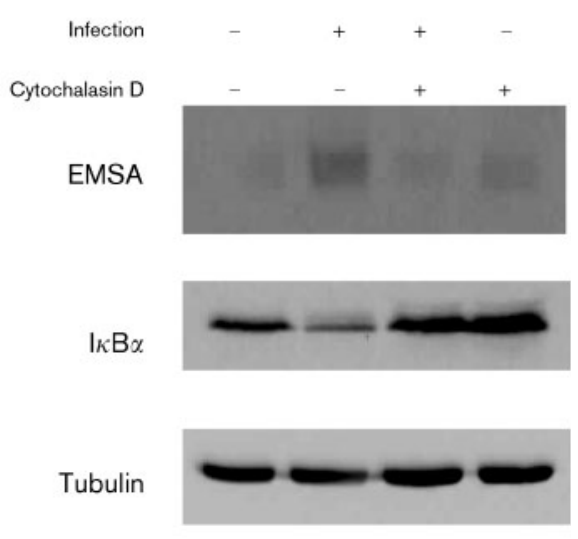

(d)

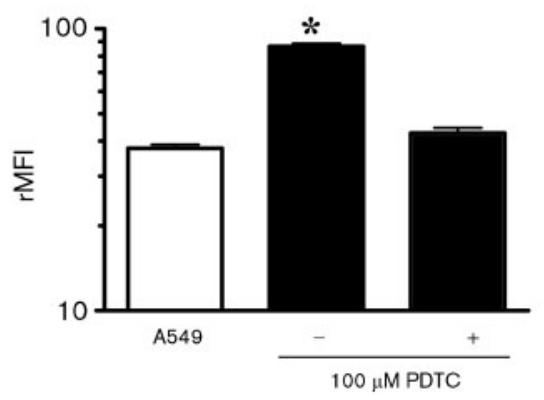

Fig. 5. (a-c) Infection with $K$. pneumoniae $52 \mathrm{~K} 10$ activates NF- $\kappa \mathrm{B}$ in airway epithelial cells. (a) Upper panel, NF- $\kappa \mathrm{B}$ binding activity was assessed by EMSA in uninfected cells (control) or cells infected with K. pneumoniae $52 \mathrm{~K} 10$ for 60 min. Middle and lower panels, immunoblots showing $\mathrm{I}_{\kappa} \mathrm{B} \alpha$ and tubulin levels, respectively, under the same conditions. (b) Upper panel, NF$\kappa \mathrm{B}$ binding activity was assessed by EMSA in infected cells in the absence or presence of cytochalasin $\mathrm{D}\left(5 \mu \mathrm{g} \mathrm{ml} \mathrm{m}^{-1}\right) . \mathrm{Middle}$ and lower panels, immunoblots showing $\mathrm{I}_{\kappa} \mathrm{B} \alpha$ and tubulin levels, respectively, under the same conditions. (c) Upper panel, immunoblot showing $I_{\kappa} \mathrm{B} \alpha$ levels in cytoplasmic extracts of NHBE cells infected with K. pneumoniae $52 \mathrm{~K} 10$ (for 60 min) in the absence or presence of cytochalasin $\mathrm{D}\left(5 \mu \mathrm{g} \mathrm{m}{ }^{-1}\right)$. Lower panel, immunoblot showing tubulin levels under the same conditions. The results in $(\mathrm{a}-\mathrm{c})$ are representative of three independent experiments. (d) The increased expression of ICAM-1 by $\mathrm{A} 549$ cells infected with $K$. pneumoniae $52 \mathrm{~K} 10$ is inhibited by PDTC, an inhibitor of NF- $\kappa$ B. Flow cytometric analysis of ICAM-1 expression by A549 cells left uninfected (white bar) or infected (black bars) in the absence or presence of $100 \mu \mathrm{M}$ PDTC, as indicated. After $2 \mathrm{~h}$ of infection, gentamicin was added to kill extracellular bacteria and $4 \mathrm{~h}$ later cells were detached, stained and analysed by flow cytometry. Results are expressed as rMFI (MFI values obtained after staining with antiICAM antibodies minus MFI values obtained after staining with isotype-matched antibodies), in arbitrary units. MFI values of A549 cells incubated with isotype matched antibodies were $9 \pm 2 .{ }^{*} P<0 \cdot 05$, a significant difference from uninfected cells.

also analysed the levels of $\mathrm{I} \kappa \mathrm{B} \alpha$, as a measure of $\mathrm{NF}-\kappa \mathrm{B}$ activation, in cytoplasmic extracts. Anti-TLR blocking antibodies abrogated the infection-dependent degradation of $\mathrm{I} \kappa \mathrm{B} \alpha$ whereas isotype-matched antibodies did not (Fig. 6b). Finally we asked whether anti-TLR blocking antibodies may alter 52K10 uptake by A549 cells. Gentamicin protection assays showed that anti-TLR antibodies reduced $52 \mathrm{~K} 10$ internalization $\left(2 \cdot 1 \pm 3 \cdot 4 \times 10^{3}\right.$ c.f.u. per monolayer versus $7 \cdot 4 \pm 0 \cdot 4 \times 10^{2}$ c.f.u. per monolayer in the presence of antibodies; $P<0.05)$. In contrast, anti-TLR antibodies did not affect $52 \mathrm{~K} 10$ attachment to A549 cells $\left(2 \cdot 4 \pm 1 \cdot 4 \times 10^{5}\right.$ c.f.u. per monolayer versus $3 \cdot 1 \pm 2 \cdot 4 \times 10^{5}$ c.f.u. per monolayer in the presence of antibodies; $P>0 \cdot 05)$. Isotype-matched antibodies altered neither internalization nor attachment of $52 \mathrm{~K} 10$ to A549 cells (data not shown).

CD14 is a $55 \mathrm{kDa}$ GPI-linked glycoprotein that also participates in pathogen recognition and uses TLRs as co-receptors in signal transduction (Van Amersfoort et al., 2003). We evaluated the cell surface expression of CD14 by flow cytometry using the well-characterized anti-CD14 monoclonal antibody My4. The results showed no significant shift in fluorescence over the fluorescence level observed with the isotype control antibody (data not shown). In host cells lacking CD14 on the surface (mCD14), soluble CD14 (sCD14) can compensate for its absence (Haziot et al., 1993, 


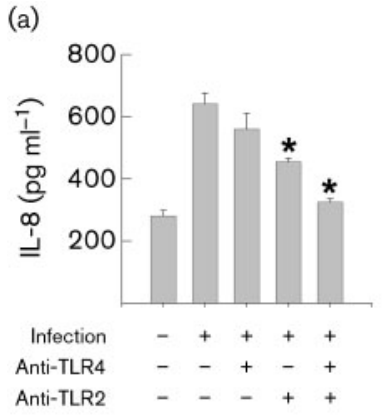

(b)

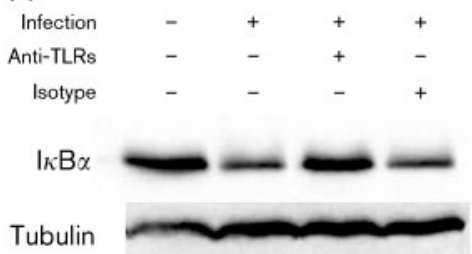

Fig. 6. Role of TLR2 and TLR4 in the activation of an inflammatory response by $\mathrm{A} 549$ cells infected with $K$. pneumoniae 52K10. (a) Cells were left uninfected or infected with K. pneumoniae $52 \mathrm{~K} 10$ in the presence or absence of anti-TLR2 blocking antibodies (clone TL2.1; $10 \mu \mathrm{g} \mathrm{ml}^{-1}$ ) and anti-TLR4 (clone HTA125; $10 \mu \mathrm{g} \mathrm{ml}^{-1}$ ) for $2 \mathrm{~h}$. Supernatants were analysed for $\mathrm{IL}-8$; the values presented are means $\pm \mathrm{SD}$. ${ }^{*} P<0 \cdot 05$, a significant difference from infected cells. (b) Upper panel, Immunoblot showing $\mid \kappa \mathrm{B} \alpha$ levels in cytoplasmic extracts of A549 cells infected with $K$. pneumoniae $52 \mathrm{~K} 10$ (for $60 \mathrm{~min}$ ) in the absence or presence of anti-TLR2 and 4 blocking antibodies or isotypematched antibodies. Lower panel, immunoblot showing tubulin levels under the same conditions. The results are representative of three independent experiments.

1996; Loppnow et al., 1995). Therefore to test the effect of CD14 on the activation of A549 cells recombinant human sCD14 was added to the culture medium. When infections were performed in the presence of $0 \cdot 1 \mu \mathrm{g} \mathrm{sCD} 14 \mathrm{ml}^{-1}$ (the minimum amount that affected IL- 8 secretion), the secretion of IL- 8 increased $30 \%$ (Fig. 7). Both anti-TLR antibodies significantly reduced IL-8 secretion (Fig. 7). 52K10 uptake by A549 cells was not affected by the presence of sCD14 (data not shown).

In summary, our results show that A549 signalling of $K$. pneumoniae infection involved TLR4 and TLR2 activation and that A549 cells could use sCD14 as TLR co-receptor.

\section{DISCUSSION}

In this work we have analysed the interplay between $K$. pneumoniae, a pathogen frequently associated with respiratory tract infections, and human airway epithelial cells. Our results showed that upon infection with the CPS mutant $52 \mathrm{~K} 10$, these cells mounted an inflammatory response characterized by elevated levels of ICAM-1 and secretion of IL-8. Importantly, this response was dependent on bacterial

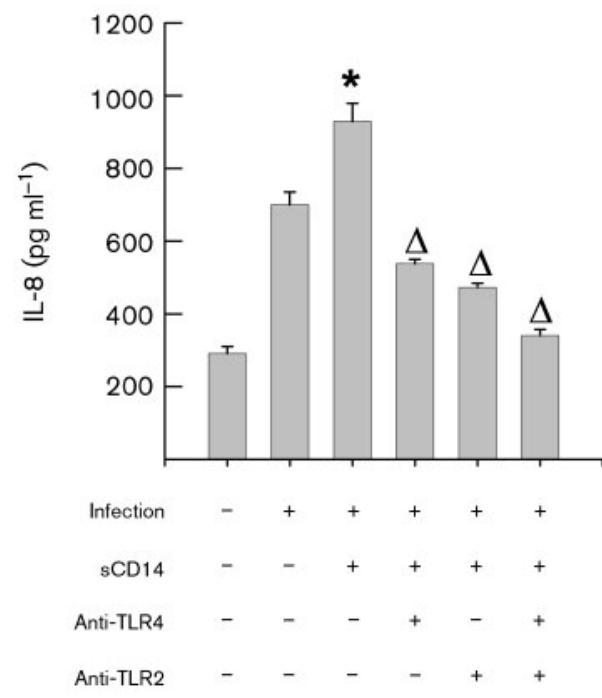

Fig. 7. Role of sCD14 in IL-8 secretion by A549 cells infected with $K$. pneumoniae 52K10. Cells were left uninfected or infected with $K$. pneumoniae $52 \mathrm{~K} 10$ in the presence or absence of $\operatorname{sCD} 14\left(0.1 \mu \mathrm{g} \mathrm{ml}^{-1}\right)$, and anti-TLR2 (clone TL2.1; $10 \mu \mathrm{g} \mathrm{ml}^{-1}$ ) and anti-TLR4 (clone HTA125; $10 \mu \mathrm{g} \mathrm{ml}^{-1}$ ) blocking antibodies for $2 \mathrm{~h}$. Supernatants were analysed for IL-8; the values presented are means $\pm S D$. ${ }^{\star} P<0.05$, a significant difference from infected cells. ${ }^{\Delta} P<0.05$, a significant difference from infected cells in the presence of SCD14.

internalization. In contrast, the wild-type strain was not internalized and it did not elicit an inflammatory response.

It is interesting to note that the connection between bacterial internalization by lung epithelial cells and the activation of an inflammatory response seems to be a general phenomenon. For example, the release of IL- 8 by A549 cells infected with group B streptococci is dependent on bacterial internalization (Doran et al., 2002). Mycoplasma pneumoniae adherence and subsequent invasion of A549 cells triggers the secretion of proinflammatory cytokines (Yang et al., 2002). Infection of A549 cells with nontypable Haemophilus influenzae also activates an inflammatory programme dependent on bacterial uptake (Frick et al., 2000; V. Regueiro \& J. A. Bengoechea, unpublished results). It is tempting to postulate that human airway epithelial cells react against an infection provided that bacteria are internalized. This scenario is similar to that described for other epithelia. Thus infection of bladder cells elicits an inflammatory response which is also dependent on bacterial internalization (Schilling et al., 2003, 2001). Elewaut et al. (1999) demonstrated that only invasive bacteria activate the expression of an inflammatory programme in intestinal epithelial cells. Taking these results together, it could be concluded that epithelial cells lining mucosal surfaces orchestrate a defence response only if pathogens are internalized. Interestingly, this is true regardless of the tissue local environment constantly exposed to microbes like the intestinal tract or essentially sterile like the urinary and respiratory tracts. 
Another common response to infection in all epithelia is the activation of NF- $\kappa \mathrm{B}$ preceded by degradation of $\mathrm{I} \kappa \mathrm{B} s$ (Elewaut et al., 1999; Schilling et al., 2003). This suggests that a common signalling pathway is activated in all cases. Evidence is accumulating that engagement of TLRs by bacterial products triggers the activation of NF- $\kappa \mathrm{B}$ and subsequently the production of cytokines and chemokines (Janeway \& Medzhitov, 2002). Therefore, we speculated that activation of airway epithelial cells by $52 \mathrm{~K} 10$ could involve TLR-dependent signalling pathways. In fact there are reports showing that $K$. pneumoniae expresses molecules, LPS and OmpA, which trigger the activation of TLRs (Branger et al., 2004; Pichavant et al., 2003; Schurr et al., 2005). Confirming our speculation, our results showed that TLR2 and TLR4 play an important role in the production of IL-8 by A549 cells upon infection with $K$. pneumoniae.

There is controversy over the surface expression of TLRs by A549 cells (Birchler et al., 2001; Monick et al., 2003; Tsutsumi-Ishii \& Nagaoka, 2003). This cell line, an adenocarcinoma line (Lieber et al., 1976), is known to differ from primary alveolar type II (ATII) cells in features such as IL-8 and nitric oxide production (Pechkovsky et al., 2002, 2000). In general, upon the same stimulus A549 cells are less responsive than ATII cells. Thus it could be speculated that TLR expression levels by A549 cells might not be as high as those by ATII cells. Recently it has been shown that A549 cells do express functional TLR2 and TLR4 on the surface, albeit at lower levels than ATII, monocytes and alveolar macrophages (Armstrong et al., 2004).

A remaining question is to link bacterial internalization, activation of TLR-dependent pathways, and the induction of an inflammatory response. Blander \& Medzhitov (2004) elegantly showed that bacterial internalization by macrophages is impaired in the absence of TLR signalling. On the other hand, Underhill et al. (1999) demonstrated that phagocytosis of bacteria by macrophages is coupled to the production of inflammatory cytokines due to the recruitment of TLRs to the phagosome. It can be concluded that TLR signalling regulates both phagocytosis and the induction of inflammatory responses upon bacterial internalization. In this context, we hypothesize that A549 cells may activate inflammatory responses in a similar fashion as macrophages. Three observations give initial support to our hypothesis: (i) internalized bacteria activated the inflammatory response; (ii) blocking antibodies against TLRs inhibited the response and impaired bacterial internalization; and (iii) 52K10 was located in phagosome-like structures (S. Albertí, unpublished results). To rigorously prove our hypothesis we are currently studying whether phagosomes containing $K$. pneumoniae are enriched with TLRs, and whether dominant-negative mutants of TLRs blunt the cell response to internalized bacteria.

To further characterize the receptors involved in the generation of infection-mediated responses, we evaluated the expression and role of CD14, a $55 \mathrm{kDa}$ GPI-linked glycoprotein that participates in pathogen recognition (Van
Amersfoort et al., 2003). There are reports showing that CD14 is critical for bacterial recognition in epithelial cells (Backhed et al., 2002; Pugin et al., 1993; Schilling et al., 2003; Van Amersfoort et al., 2003). Our results showed that A549 cells did not express mCD14, which is consistent with previous observations (Schulz et al., 2002). However, it has been shown that the expression of this molecule in cultured human nonmyeloid cells decreases over time (Jersmann et al., 2001); therefore we cannot rule out the possibility that human alveolar epithelial cells express mCD14. Nevertheless, our results showed that A549 cells could use sCD14 as TLR co-receptor to recognize bacterial pathogens. An important issue is whether sCD14 would be present in the airways. The current data indicate that this is possible. There are reports showing that sCD14 is present in bronchoalveolar fluid of healthy subjects and that the amount of sCD14 is increased under inflammatory conditions (Martin et al., 1997). However, at present it is not clear what is the natural source of sCD14 within the airways, although it is known that $\mathrm{SCD} 14$ is highly abundant in plasma (in the microgram range). Recent results obtained in our laboratory indicate that epithelial cells may serve as one possible source because A549 and NHBE cells primed with inflammatory cytokines release sCD14 (V. Regueiro \& J. A. Bengoechea, unpublished results).

Neutrophil infiltration into airways is a common histological finding in patients with pneumonia, independently of the infecting micro-organism. In the case of infections caused by K. pneumoniae, animal experiments have revealed that mice unable to recruit neutrophils into lung tissues display greater bacterial loads in the lungs (Greenberger et al., 1996). In this model of pneumonia, chemokines KC and MIP-2, functional mouse homologues of IL-8, are responsible for the targeting of neutrophils to sites of attack (Greenberger et al., 1996). Furthermore, transgenic mice overexpressing KC show an improvement in survival due to an increase in $K$. pneumoniae clearance, which occurs in association with enhanced influx of neutrophils to the lungs (Tsai et al., 1998). In this work we have shown that IL-8 enhanced the killing ability of neutrophils against $K$. pneumoniae. Collectively, these findings illustrate the importance of IL-8 secreted by airway epithelial cells in the activation of pulmonary innate immune responses after bacterial infection. In turn, the fact that wild-type K. pneumoniae does not elicit the secretion of IL- 8 by airway epithelial cells would be important in the setting of pneumonia. These findings are in good agreement with data obtained in a murine model of pneumonia. Thus at early time points capsulated $K$. pneumoniae induces less inflammatory mediators and less infiltration of inflammatory cells than a capsule mutant (Yoshida et al., 2000). In addition, the establishment of pneumonia will be facilitated by the attenuation of host defence caused by the elevated levels of IL-10 induced by capsulated K. pneumoniae (Greenberger et al., 1995; Yoshida et al., 2001). At present the cellular source(s) of IL-10 is not clear. This cytokine could be produced by a variety of cells, including lymphocytes, macrophages and epithelial cells 
(Howard et al., 1992). However, our results suggest that airway epithelial cells might not be the cellular source of IL-10. In contrast, we have found induction of IL-10 secretion by alveolar macrophages cultured in the presence of capsulated K. pneumoniae (V. Regueiro \& J. A. Bengoechea, unpublished results). Studies are ongoing to determine the cellular sources of IL-10 within the lung.

In summary, our findings are consistent with a scenario in which the CPS of K. pneumoniae, by inhibiting the adhesion and phagocytosis of the bacteria, prevents the secretion of IL- 8 by airway epithelial cells and hence the activation of the innate immune system.

\section{ACKNOWLEDGEMENTS}

We are grateful to members of the Bengoechea lab for helpful discussions and to Jeronia Lladó for critically reading the manuscript. Fellowship support to M. A. C. from Govern Illes Balears is gratefully acknowledged. J. A. B. is the recipient of a 'Contrato de Investigador' from Fondo de Investigación Sanitaria. This work has been funded by grants from Fondo de Investigación Sanitaria (PI01/3095 and PI03/ 0881 to J. A. B.), Govern Balear (PRIB-2004-10075 to J. A. B.) and Red Respira (RTIC C03/11, Instituto de Salud Carlos III, Spain).

\section{REFERENCES}

Armstrong, L., Medford, A. R., Uppington, K. M., Robertson, J., Witherden, I. R., Tetley, T. D. \& Millar, A. B. (2004). Expression of functional Toll-like receptor (TLR-)2 and TLR-4 on alveolar epithelial cells. Am J Respir Cell Mol Biol 31, 241-245.

Backhed, F., Meijer, L., Normark, S. \& Richter-Dahlfors, A. (2002). TLR4-dependent recognition of lipopolysaccharide by epithelial cells requires sCD14. Cell Microbiol 4, 493-501.

Bayram, H., Devalia, J. L., Sapsford, R. J., Ohtoshi, T., Miyabara, Y., Sagai, M. \& Davies, R. J. (1998). The effect of diesel exhaust particles on cell function and release of inflammatory mediators from human bronchial epithelial cells in vitro. Am J Respir Cell Mol Biol 18, 441-448.

Birchler, T., Seibl, R., Buchner, K., Loeliger, S., Seger, R., Hossle, J. P., Aguzzi, A. \& Lauener, R. P. (2001). Human Toll-like receptor 2 mediates induction of the antimicrobial peptide human betadefensin 2 in response to bacterial lipoprotein. Eur J Immunol 31, 3131-3137.

Blander, J. M. \& Medzhitov, R. (2004). Regulation of phagosome maturation by signals from Toll-like receptors. Science 304, 1014-1018.

Branger, J., Knapp, S., Weijer, S., Leemans, J. C., Pater, J. M., Speelman, P., Florquin, S. \& van der Poll, T. (2004). Role of Tolllike receptor 4 in gram-positive and gram-negative pneumonia in mice. Infect Immun 72, 788-794.

Bullard, D. C., Qin, L., Lorenzo, I., Quinlin, W. M., Doyle, N. A., Bosse, R., Vestweber, D., Doerschuk, C. M. \& Beaudet, A. L. (1995). P-selectin/ICAM-1 double mutant mice: acute emigration of neutrophils into the peritoneum is completely absent but is normal into pulmonary alveoli. J Clin Invest 95, 1782-1788.

Chertov, O., Michiel, D. F., Xu, L., Wang, J. M., Tani, K., Murphy, W. J., Longo, D. L., Taub, D. D. \& Oppenheim, J. J. (1996). Identification of defensin-1, defensin-2, and CAP37/azurocidin as T-cell chemoattractant proteins released from interleukin-8-stimulated neutrophils. J Biol Chem 271, 2935-2940.
Cortes, G., Alvarez, D., Saus, C. \& Alberti, S. (2002a). Role of lung epithelial cells in defense against Klebsiella pneumoniae pneumonia. Infect Immun 70, 1075-1080.

Cortes, G., Borrell, N., de Astorza, B., Gomez, C., Sauleda, J. \& Alberti, S. (2002b). Molecular analysis of the contribution of the capsular polysaccharide and the lipopolysaccharide $\mathrm{O}$ side chain to the virulence of Klebsiella pneumoniae in a murine model of pneumonia. Infect Immun 70, 2583-2590.

Doran, K. S., Chang, J. C., Benoit, V. M., Eckmann, L. \& Nizet, V. (2002). Group B streptococcal beta-hemolysin/cytolysin promotes invasion of human lung epithelial cells and the release of interleukin8. J Infect Dis 185, 196-203.

Elewaut, D., DiDonato, J. A., Kim, J. M., Truong, F., Eckmann, L. \& Kagnoff, M. F. (1999). NF- $\kappa \mathrm{B}$ is a central regulator of the intestinal epithelial cell innate immune response induced by infection with enteroinvasive bacteria. J Immunol 163, 1457-1466.

Favre-Bonte, S., Joly, B. \& Forestier, C. (1999). Consequences of reduction of Klebsiella pneumoniae capsule expression on interactions of this bacterium with epithelial cells. Infect Immun 67, 554-561.

Frick, A. G., Joseph, T. D., Pang, L., Rabe, A. M., St Geme, J. W., III \& Look, D. C. (2000). Haemophilus influenzae stimulates ICAM-1 expression on respiratory epithelial cells. J Immunol 164, 4185-4196.

Greenberger, M. J., Strieter, R. M., Kunkel, S. L., Danforth, J. M., Goodman, R. E. \& Standiford, T. J. (1995). Neutralization of IL-10 increases survival in a murine model of Klebsiella pneumonia. J Immunol 155, 722-729.

Greenberger, M. J., Strieter, R. M., Kunkel, S. L., Danforth, J. M., Laichalk, L. L., McGillicuddy, D. C. \& Standiford, T. J. (1996). Neutralization of macrophage inflammatory protein-2 attenuates neutrophil recruitment and bacterial clearance in murine Klebsiella pneumonia. J Infect Dis 173, 159-165.

Haziot, A., Rong, G. W., Silver, J. \& Goyert, S. M. (1993). Recombinant soluble CD14 mediates the activation of endothelial cells by lipopolysaccharide. J Immunol 151, 1500-1507.

Haziot, A., Ferrero, E., Kontgen, F., Hijiya, N., Yamamoto, S., Silver, J., Stewart, C. L. \& Goyert, S. M. (1996). Resistance to endotoxin shock and reduced dissemination of gram-negative bacteria in CD14-deficient mice. Immunity 4, 407-414.

Hellermann, G. R., Nagy, S. B., Kong, X., Lockey, R. F. \& Mohapatra, S. S. (2002). Mechanism of cigarette smoke condensate-induced acute inflammatory response in human bronchial epithelial cells. Respir Res 3, 22.

Hoshino, Y., Mio, T., Nagai, S., Miki, H., Ito, I. \& Izumi, T. (2001). Cytotoxic effects of cigarette smoke extract on an alveolar type II cell-derived cell line. Am J Physiol Lung Cell Mol Physiol 281, L509-L516.

Howard, M., O'Garra, A., Ishida, H., de Waal, M. R. \& de Vries, J. (1992). Biological properties of interleukin 10. J Clin Immunol 12, 239-247.

Janeway, C. A., Jr \& Medzhitov, R. (2002). Innate immune recognition. Annu Rev Immunol 20, 197-216.

Jersmann, H. P., Hii, C. S., Hodge, G. L. \& Ferrante, A. (2001). Synthesis and surface expression of CD14 by human endothelial cells. Infect Immun 69, 479-485.

Lee, J. H., Del Sorbo, L., Uhlig, S., Porro, G. A., Whitehead, T., Voglis, S., Liu, M., Slutsky, A. S. \& Zhang, H. (2004). Intercellular adhesion molecule-1 mediates cellular cross-talk between parenchymal and immune cells after lipopolysaccharide neutralization. J Immunol 172, 608-616.

Lieber, M., Smith, B., Szakal, A., Nelson-Rees, W. \& Todaro, G. (1976). A continuous tumor-cell line from a human lung carcinoma with properties of type II alveolar epithelial cells. Int J Cancer 17, 62-70. 
Lien, E., Sellati, T. J., Yoshimura, A. \& 8 other authors (1999). Tolllike receptor 2 functions as a pattern recognition receptor for diverse bacterial products. J Biol Chem 274, 33419-33425.

Look, D. C., Rapp, S. R., Keller, B. T. \& Holtzman, M. J. (1992). Selective induction of intercellular adhesion molecule-1 by interferon-gamma in human airway epithelial cells. Am J Physiol 263, L79-L87.

Loppnow, H., Stelter, F., Schonbeck, U., Schluter, C., Ernst, M., Schutt, C. \& Flad, H. D. (1995). Endotoxin activates human vascular smooth muscle cells despite lack of expression of CD14 mRNA or endogenous membrane CD14. Infect Immun 63, 1020-1026.

Martin, T. R., Rubenfeld, G. D., Ruzinski, J. T. \& 7 other authors (1997). Relationship between soluble CD14, lipopolysaccharide binding protein, and the alveolar inflammatory response in patients with acute respiratory distress syndrome. Am J Respir Crit Care Med 155, 937-944.

Mastronarde, J. G., Monick, M. M., Mukaida, N., Matsushima, K. \& Hunninghake, G. W. (1998). Activator protein-1 is the preferred transcription factor for cooperative interaction with nuclear factor$\kappa \mathrm{B}$ in respiratory syncytial virus-induced interleukin- 8 gene expression in airway epithelium. J Infect Dis 177, 1275-1281.

Mikamo, H., Johri, A. K., Paoletti, L. C., Madoff, L. C. \& Onderdonk, A. B. (2004). Adherence to, invasion by, and cytokine production in response to serotype VIII group B streptococci. Infect Immun 72, $4716-4722$.

Mio, T., Romberger, D. J., Thompson, A. B., Robbins, R. A., Heires, A. \& Rennard, S. I. (1997). Cigarette smoke induces interleukin-8 release from human bronchial epithelial cells. Am J Respir Crit Care Med 155, 1770-1776.

Monick, M. M., Yarovinsky, T. O., Powers, L. S., Butler, N. S., Carter, A. B., Gudmundsson, G. \& Hunninghake, G. W. (2003). Respiratory syncytial virus up-regulates TLR4 and sensitizes airway epithelial cells to endotoxin. J Biol Chem 278, 53035-53044.

Moodie, F. M., Marwick, J. A., Anderson, C. S., Szulakowski, P., Biswas, S. K., Bauter, M. R., Kilty, I. \& Rahman, I. (2004). Oxidative stress and cigarette smoke alter chromatin remodeling but differentially regulate NF- $\kappa \mathrm{B}$ activation and proinflammatory cytokine release in alveolar epithelial cells. FASEB J 18, 1897-1899.

Murdoch, C., Read, R. C., Zhang, Q. \& Finn, A. (2002). Cholinebinding protein A of Streptococcus pneumoniae elicits chemokine production and expression of intercellular adhesion molecule 1 (CD54) by human alveolar epithelial cells. J Infect Dis 186, 1253-1260.

Nakajima, S., Look, D. C., Roswit, W. T., Bragdon, M. J. \& Holtzman, M. J. (1994). Selective differences in vascular endothelial- vs. airway epithelial-T cell adhesion mechanisms. Am J Physiol 267, L422-L432.

Nakajima, S., Roswit, W. T., Look, D. C. \& Holtzman, M. J. (1995). A hierarchy for integrin expression and adhesiveness among $\mathrm{T}$ cell subsets that is linked to TCR gene usage and emphasizes V delta $1+$ gamma delta $\mathrm{T}$ cell adherence and tissue retention. J Immunol 155, 1117-1131.

Nakamura, H., Yoshimura, K., Jaffe, H. A. \& Crystal, R. G. (1991). Interleukin-8 gene expression in human bronchial epithelial cells. J Biol Chem 266, 19611-19617.

Nassif, X., Fournier, J. M., Arondel, J. \& Sansonetti, P. J. (1989). Mucoid phenotype of Klebsiella pneumoniae is a plasmid-encoded virulence factor. Infect Immun 57, 546-552.

Nishikawa, M., Kakemizu, N., Ito, T., Kudo, M., Kaneko, T., Suzuki, M., Udaka, N., Ikeda, H. \& Okubo, T. (1999). Superoxide mediates cigarette smoke-induced infiltration of neutrophils into the airways through nuclear factor- $\kappa \mathrm{B}$ activation and IL- 8 mRNA expression in guinea pigs in vivo. Am J Respir Cell Mol Biol 20, 189-198.

O'Brien, A. D., Standiford, T. J., Bucknell, K. A., Wilcoxen, S. E. \& Paine, R., III, (1999). Role of alveolar epithelial cell intercellular adhesion molecule-1 in host defense against Klebsiella pneumoniae. Am J Physiol 276, L961-L970.

Oelschlaeger, T. A. \& Tall, B. D. (1997). Invasion of cultured human epithelial cells by Klebsiella pneumoniae isolated from the urinary tract. Infect Immun 65, 2950-2958.

Paine, R., III, Morris, S. B., Jin, H., Baleeiro, C. E. \& Wilcoxen, S. E. (2002). ICAM-1 facilitates alveolar macrophage phagocytic activity through effects on migration over the AEC surface. Am J Physiol Lung Cell Mol Physiol 283, L180-L187.

Papi, A., Papadopoulos, N. G., Degitz, K., Holgate, S. T. \& Johnston, S. L. (2000). Corticosteroids inhibit rhinovirus-induced intercellular adhesion molecule-1 up-regulation and promoter activation on respiratory epithelial cells. J Allergy Clin Immunol 105, 318-326.

Pathmanathan, S., Krishna, M. T., Blomberg, A., Helleday, R., Kelly, F. J., Sandstrom, T., Holgate, S. T., Wilson, S. J. \& Frew, A. J. (2003). Repeated daily exposure to $2 \mathrm{ppm}$ nitrogen dioxide upregulates the expression of IL-5, IL-10, IL-13, and ICAM-1 in the bronchial epithelium of healthy human airways. Occup Environ Med 60, 892-896.

Pechkovsky, D. V., Zissel, G., Ziegenhagen, M. W. \& 7 other authors (2000). Effect of proinflammatory cytokines on interleukin-8 mRNA expression and protein production by isolated human alveolar epithelial cells type II in primary culture. Eur Cytokine Netw 11, 618-625.

Pechkovsky, D. V., Zissel, G., Goldmann, T., Einhaus, M., Taube, C., Magnussen, H., Schlaak, M. \& Muller-Quernheim, J. (2002). Pattern of NOS2 and NOS3 mRNA expression in human A549 cells and primary cultured AEC II. Am J Physiol Lung Cell Mol Physiol 282, L684-L692.

Pichavant, M., Delneste, Y., Jeannin, P., Fourneau, C., Brichet, A., Tonnel, A. B. \& Gosset, P. (2003). Outer membrane protein A from Klebsiella pneumoniae activates bronchial epithelial cells: implication in neutrophil recruitment. J Immunol 171, 6697-6705.

Poynter, M. E., Irvin, C. G. \& Janssen-Heininger, Y. M. (2002). Rapid activation of nuclear factor- $\kappa \mathrm{B}$ in airway epithelium in a murine model of allergic airway inflammation. Am J Pathol 160, 1325-1334.

Poynter, M. E., Irvin, C. G. \& Janssen-Heininger, Y. M. (2003). A prominent role for airway epithelial NF- $\kappa \mathrm{B}$ activation in lipopolysaccharide-induced airway inflammation. J Immunol 170, 6257-6265.

Pugin, J., Schurer-Maly, C. C., Leturcq, D., Moriarty, A., Ulevitch, R. J. \& Tobias, P. S. (1993). Lipopolysaccharide activation of human endothelial and epithelial cells is mediated by lipopolysaccharidebinding protein and soluble CD14. Proc Natl Acad Sci U S A 90, 2744-2748.

Schilling, J. D., Mulvey, M. A., Vincent, C. D., Lorenz, R. G. \& Hultgren, S. J. (2001). Bacterial invasion augments epithelial cytokine responses to Escherichia coli through a lipopolysaccharidedependent mechanism. J Immunol 166, 1148-1155.

Schilling, J. D., Martin, S. M., Hunstad, D. A., Patel, K. P., Mulvey, M. A., Justice, S. S., Lorenz, R. G. \& Hultgren, S. J. (2003). CD14and Toll-like receptor-dependent activation of bladder epithelial cells by lipopolysaccharide and type I piliated Escherichia coli. Infect Immun 71, 1470-1480.

Schreck, R., Meier, B., Mannel, D. N., Droge, W. \& Baeuerle, P. A. (1992). Dithiocarbamates as potent inhibitors of nuclear factor kappa B activation in intact cells. J Exp Med 175, 1181-1194.

Schulz, C., Farkas, L., Wolf, K., Kratzel, K., Eissner, G. \& Pfeifer, M. (2002). Differences in LPS-induced activation of bronchial epithelial cells (BEAS-2B) and type II-like pneumocytes (A-549). Scand J Immunol 56, 294-302.

Schurr, J. R., Young, E., Byrne, P., Steele, C., Shellito, J. E. \& Kolls, J. K. (2005). Central role of Toll-like receptor 4 signaling and host defense in experimental pneumonia caused by Gram-negative bacteria. Infect Immun 73, 532-545. 
Shimazu, R., Akashi, S., Ogata, H., Nagai, Y., Fukudome, K., Miyake, K. \& Kimoto, M. (1999). MD-2, a molecule that confers lipopolysaccharide responsiveness on Toll-like receptor 4. J Exp Med 189, 1777-1782.

Tosi, M. F., Stark, J. M., Hamedani, A., Smith, C. W., Gruenert, D. C. \& Huang, Y. T. (1992). Intercellular adhesion molecule-1 (ICAM-1)dependent and ICAM-1-independent adhesive interactions between polymorphonuclear leukocytes and human airway epithelial cells infected with parainfluenza virus type 2. J Immunol 149, 3345-3349.

Tosi, M. F., Stark, J. M., Smith, C. W., Hamedani, A., Gruenert, D. C. \& Infeld, M. D. (1992). Induction of ICAM-1 expression on human airway epithelial cells by inflammatory cytokines: effects on neutrophil-epithelial cell adhesion. Am J Respir Cell Mol Biol 7, 214-221.

Tsai, W. C., Strieter, R. M., Wilkowski, J. M., Bucknell, K. A., Burdick, M. D., Lira, S. A. \& Standiford, T. J. (1998). Lung-specific transgenic expression of $\mathrm{KC}$ enhances resistance to Klebsiella pneumoniae in mice. J Immunol 161, 2435-2440.

Tsutsumi-Ishii, Y. \& Nagaoka, I. (2003). Modulation of human betadefensin-2 transcription in pulmonary epithelial cells by lipopolysaccharide-stimulated mononuclear phagocytes via proinflammatory cytokine production. J Immunol 170, 4226-4236.

Underhill, D. M., Ozinsky, A., Hajjar, A. M., Stevens, A., Wilson, C. B., Bassetti, M. \& Aderem, A. (1999). The Toll-like receptor 2 is recruited to macrophage phagosomes and discriminates between pathogens. Nature 401, 811-815.
Van Amersfoort, E. S., Van Berkel, T. J. \& Kuiper, J. (2003). Receptors, mediators, and mechanisms involved in bacterial sepsis and septic shock. Clin Microbiol Rev 16, 379-414.

Videm, V. \& Strand, E. (2004). Changes in neutrophil surfacereceptor expression after stimulation with FMLP, endotoxin, interleukin- 8 and activated complement compared to degranulation. Scand J Immunol 59, 25-33.

Witherden, I. R., Vanden Bon, E. J., Goldstraw, P., Ratcliffe, C., Pastorino, U. \& Tetley, T. D. (2004). Primary human alveolar type II epithelial cell chemokine release: effects of cigarette smoke and neutrophil elastase. Am J Respir Cell Mol Biol 30, 500-509.

Yamamura, M., Hinoda, Y., Sasaki, S., Tsujisaki, M., Oriuchi, N., Endo, K. \& Imai, K. (1996). A human/mouse chimeric monoclonal antibody against intercellular adhesion molecule-1 for tumor radioimmunoimaging. Jpn J Cancer Res 87, 405-411.

Yang, J., Hooper, W. C., Phillips, D. J. \& Talkington, D. F. (2002). Regulation of proinflammatory cytokines in human lung epithelial cells infected with Mycoplasma pneumoniae. Infect Immun 70, 3649-3655.

Yoshida, K., Matsumoto, T., Tateda, K., Uchida, K., Tsujimoto, S. \& Yamaguchi, K. (2000). Role of bacterial capsule in local and systemic inflammatory responses of mice during pulmonary infection with Klebsiella pneumoniae. J Med Microbiol 49, 1003-1010.

Yoshida, K., Matsumoto, T., Tateda, K., Uchida, K., Tsujimoto, S. \& Yamaguchi, K. (2001). Induction of interleukin-10 and downregulation of cytokine production by Klebsiella pneumoniae capsule in mice with pulmonary infection. J Med Microbiol 50, 456-461. 